\title{
PENGARUH MODEL DISCOVERY LEARNING DENGAN PENDEKATAN SCIENTIFIC BERBASIS E-BOOK PADA MATERI RANGKAIAN INDUKTOR TERHADAP HASIL BELAJAR SISWA
}

\author{
Arifah Budiarti ${ }^{1}$, Jeffry Handhika ${ }^{2}$, Sulistyaning Kartikawati ${ }^{3}$ \\ ${ }^{1,3}$ Pendidikan Teknik Elektro, Universitas PGRI Madiun \\ Madiun, 63118, Indonesia \\ ${ }^{2}$ Pendidikan Fisika, FKIP, Universitas PGRI Madiun \\ Madiun, 63118, Indonesia \\ Email: adja761@gmail.com; jhandhika@unipma.ac.id; sulistyaningk@ gmail.com
}

\begin{abstract}
Abstrak. Penelitian ini bertujuan untuk mengetahui adanya pengaruh model discovery learning dengan pendekatan scientific berbasise-book interaktif pada materi Rangkaian Induktor terhadap hasil belajar siswa. Penelitian ini berbentuk penelitian kuantitatif. Sampel yang digunakansatu kelas, diambil menggunakan metode Scientificdengan dengan penerapan media pembelajaran yaitu salah satunya E-book. Penelitian ini berbentuk penelitian kuantitatif. Sampel yang digunakan satu kelas, diambil menggunakan teknik sampling jenuh dengan kelas sebelum perlakuan (pretest) diajar dengan mentode konvensional/ceramah dan kelas sesudah perlakuan (posttest) diajar dengan media pembelajaran e-book. Teknik pengumpulan data menggunakan metode tes tulispilihanganda untuk data hasil belajar mahasiswa.Teknikanalisis data menggunakan korelasi product moment. Teknik analisis data menggunakan ujikorelasi product moment.Hasil uji hipotesis bahwa $\mathrm{r}_{\mathrm{xy}}$ hitung sebesar 0,951dan $\mathrm{r}_{\mathrm{xy} \text { tabel }}$ pada taraf signifikansi $5 \%$ adalah 0,444 . Ini berarti $\mathrm{r}_{\mathrm{xy} \text { hitung }}>\mathrm{r}_{\mathrm{xytabel}}$, sehingga $\mathrm{H}_{\mathrm{a}}: \mu_{1}=$ $\mu_{2}$ maka $\mathrm{H}_{\mathrm{o}}$ ditolak ( $\mathrm{H}_{\mathrm{a}}$ diterima) Jadi, dapat disimpulkan bahwa ada pengaruh penerapanmedia pembelajaran E-book dengan pendekatan scientific untukmeningkatkanhasilbelajar siswa pada mata pelajaran Rangkaian Induktor.
\end{abstract}

Kata Kunci :Discovery Learning, Scientific, E-book, Hasil Belajar Siswa.

\section{Pendahuluan}

Dalam Undang-Undang No.20 Tahun 2003 tentang Sistem Pendidikan Nasional menyatakan bahwa pendidikan adalah usaha sadar dan terencana untuk mewujudkan suasana dan proses belajar dan proses pembelajaran agar peserta didik secara aktif mengembangkan potensi dirinya untuk memiliki kekuatan spiritual keagamaan pengendalian diri, kepribadian, kecerdasan akhlak, mulia serta keterampilan yang diperlukan dirinya, masyarakat bangsa dan Negara.

Rangkaian induktor merupakan materi pelajaran dasar dan pengukuran listrik yang diajarkan di kelas X SMK. Dalam materi ini dimana siswa dituntut untuk memahami konsep terlebih dahulu kemudian mengaplikasikannya ke dalam bentuk perhitungan, sehingga siswa dapat menentukan nilai induktansi total dari rangkaian seri,paralel dan campuran. Untuk mengajarkan materi ini, memerlukan strategi pembelajaran yang membuat siswa dapat memahami konsep dan mengaplikasikannya.

Pernyataan tersebut sesuai dengan pengamatan peneliti selama PPL di SMK Gamaliel 1 Madiun yang menunjukkan bahwa nilai rata-rata kelas pada materi rangkaian induktor yaitu 75. Hal ini disebabkan karena interaksi antara guru dan siswa masih kurang, pembelajarannya masih bersifat konvensional melalui metode ceramah yang disampaikan oleh guru, media yang digunakan berupa power point dengan slide yang kurang menarik bagi siswa, sehingga siswa akan merasa jenuh terhadap materi tersebut dan siswa tidak terlibat aktif yang menyebabkan hasil belajar siswa menurun. Perkembangan yang terjadi pada buku sejak ditemukannya teks yang kemudian berevolusi menjadi buku cetak dan sekarang berkembang 
menjadi buku digital atau yang biasanya disebut dengan $e$-book. Dengan adanya hand phone berbasis android siswa juga dapat mengakses ebook ini, sehingga siswa dapat belajar melalui ebook yang di download dari hand phone dan siswa tidak akan kerepotan membawa buku yang tidak bisa dimasukkan ke saku celana atau baju layaknya hand phone. Karater siswa yang ingin dibangun dalam penelitian ini adalah rasa ingintahu dan tanggung jawab yang sesuai dengan nilai karakter yang dapat dibangun jika ditinjau mata pelajaran dasar dan pengukuran listrik dengan metode saintifik.

Pendekatan scientific menjadikan pembelajaran lebih aktif dan tidak membosankan, siswa dapat mengonstruksi pengetahuan dan keterampilannya melalui fakta-fakta yang ditemukan dalam penyelidikan di lapangan guna pembelajaran. Dengan model Pembelajaran discovery learning mengarahkan peserta didik untuk memahami konsep arti, dan hubungan, melalui proses intuitif untuk akhirnya sampaik kepada suatu kesimpulan. Penemuan konsep tidak disajikan dalam bentuk akhir, tetapi peserta didik didorong untuk mengidentifikasi apa yang ingin diketahui dan dilanjutkan dengan mencari informasi sendiri kemudian mengorganisasi atau mengkonstruksi apa yang mereka ketahui dan pahami dalam suatu bentuk akhir.

Kemajuan teknologi informasi dan komunikasi yang begitu pesat menawarkan berbagai kemudahan baru dalam pembelajaran, pembelajaran merupakan proses terjadinya interaksi antara peserta didik dengan guru, namun proses pembelajaran yang berlangsung kenyataannya sebagian besar masih berpusat pada pengajar, dimana proses pembelajaran yang berkualitas idealnya adalah sejalan dengan berkembangnya $e$-jurnal, telah berkembang pula $e$-book. Dari uraian di atas, maka peneliti ini mengkaji tentang pengaruh model discovery learning dengan pendekatan scientific berbasis e-book pada materi rangkaian induktor terhadap hasil belajar siswa. Dengan media $e$-book ini siswa diharapkan lebih aktif dan meningkat dalam prestasi.

Berdasarkan uraian diatas, maka yang menjadi fokus kajian dalam penelitian ini adalah pengaruh penerapan discovery learning dengan pendekatan scientific berbasis ebook pada materi rangkaian induktor terhadap hasil belajar siswa.

Beberapa penjelasan tentang belajar Menurut siregar \& Nara (2011: 3) menyebutkan "belajar merupakan sebuah proses yang kompleks yang terjadi pada semua orang dan berlangsung seumur hidup, sejak masih bayi (bahkan dalam kandungan) hingga liang lahat". Belajar adalah sebuah kompleks yang di dalamnya terkandung beberapa aspek.Aspek-aspek menurut siregar \& Nara (2007: 4-5) tersebut adalah "bertambahnya jumlah pengetahuaan, adanya kemampuan mengingat dan mereproduksi, ada penerapan pengetahuan, menyimpulkan makna, menafsirkan dan mengaitkannya dengan realitas, adanya perubahan sebagai pribadi”.

Menurut Slameto (2010: 2) pengertian belajar dapat didefinisikan sebagi berikut : "Belajar adalah suatu proses usaha yang dilakukan seseorang untuk memperoleh suatu perubahan tingkah laku yang baru secara keseluruhan, sebagai hasil pengalamannya sendiri dalam interaksi dengan linkungannya". Adapun ciri-ciri pengertian belajar dalam perubahan tingkah laku menurut Slameto (2010: 3-4) yaitu "perubahan secara sadar, Perubahan dalam belajar bersifat kontinu dan fungsional, Perubahan dalam belajar bersifat positif dan aktif, Perubahan dalam belajar bukan bersifat sementara, Perubahan dalam belajar bertujuan atau terarah, Perubahan mencangkup aspek tingkah laku".

Arsyad (2015: 3) mengungkapkan bahwa "kata media berasal dari bahasa latin medius yang secara harfiah berarti 'tengah', 'perantara' atau 'pengantar'. Dalam bahasa Arab, media adalah perantara atau pengantar pesan dari pengirim kepada penerima pesan. Secara lebih khusus, pengertian media dalam proses belajar mengajar cenderung diartikan sebagai alat-alat 
grafis, photografis, atau elektronis untuk menangkap, memproses, dan menyusun kembali informasi visual atau verbal".

Fungsi media pembelajaran menurut Arsyad (2014: 19) adalah "sebagai alat bantu mengajar yang turut mempengaruhi iklim, kondisi, dan lingkungan belajar yang ditata dan diciptakan oleh guru". Fungsi dari media pendidikan menurut Sadiman, dkk (2011: 17-18) adalah untuk memperjelas penyajian pesan agar tidak terlalu bersifat verbalistis, mengatasi keterbatasan ruang, waktu dan daya indra, dan penggunaan media pendidikan secara tepat dan bervariasi dapat mengatasi sikap pasif anak didik. dengan sifat yang unik pada tiap siswa ditambah lagi dengan lingkungan dan pengalaman yang berbeda, sedangkan kurikulum dan materi pendidikan ditentukan sama untuk setiap siswa, maka guru banyak mngalami kesulitan bilamana semuanya itu diatasi sendiri.

Menurut Suryani \& Agung (2012: 8), model pembelajaran dapat diartikan sebagai pola yang digunakan untuk penyusunan kurikulum, pengaturan materi dan memberi petunjuk kepada guru di kelas. Menurut Suryani \& Agung (2012: 25) "pendekatan inquiry merupakan pendekatan mengajar yang berusaha meletakan dasar dan pengembangan cara berfikir ilmiah"

Menurut Tumurun, dkk (2016: 109) pembelajaran dengan menggunakan model discovery learning lebih mampu meningkatkan keterampilan berfikir kreatif siswa dibandingkan dengan model pembelajaran konvensional. Hal ini dikarenakan dalam model pembelajaran konvensional tidak memiliki komponen-komponen atau tahap-tahap pembelajaran seperti model discovery learning. Tahapan-tahapan model discovery learning memberikan kesempatan kepada siswa untuk melatih setiap indikator keterampilan berpikir kreatifnya

Menurut Ine (2015: 271) "Pendekatan scientific merupakan pendekatan dalam proses pembelajaran yang mengintergrasikan keterampilan sains yaitu mencari tahu sendiri faktafakta dan pengetahuan yang dikaitkan dengan materi pembelajaran". Tujuan pembelajaran dengan pendekatan scientific didasarkan pada keunggulan pendekatan tersebut.

Proses pembelajaran pada kurikulum 2013 untuk semua jenjang dilaksankan dengan menggunakan pendekatan scientific. Langkah-langkah dalam pendekatan scientific dikatakan sebagai pembelajaran terhadap pengetahuan ilmiah yang diatur oleh pertimbanganpertimbangan logis dalam ilmu-ilmu sosial termasuk juga ilmu ekonomi.

Menurut Koriyati \&Manggala (2016: 238-239) Secara sederhana $e$-book dapat diartikan sebagai buku elektronik atau buku digital.Buku elektronik adalah versi digital dari buku yang umumnya terdiri dari kumpulan kerta yang berisi teks atau gambar.Visi dari e-book adalah sebagai format alternatif sebuah buku/document yang dapat di download dan dibaca dengan mudah kapan pun dan di mana pun.E-Book sendiri menjadi sangat bermanfaat untuk mengatasi kekurangan buku cetak di kurikulum 2013 dan mengurangi biaya yang di keluarkan untuk membeli buku.

Materi rangkaian induktor menurut Widodo (2013: 80-82) adalah "sebuah elemen pasif rangkaian yang dapat menyimpan energi". Induktor berbentuk sebuah lilitan yang terbuat dari bahan konduktor yang dililitkan pada suatu bahan feromagnetik. Sebuah induktor atau reaktor adalah sebuah komponen elektronika pasif yang dapat menyimpan energi pada medan magnet yang ditimbulkan oleh arus listrik yang melintasinya. Kemampuan induktor untuk menyimpan energi magnet ditentukan oleh induktansinya (L), yang diukur dalam satuan Henry. Biasanya sebuah induktor adalah sebuah kawat penghantar yang dibentuk menjadi kumparan, lilitan membantu membuat medan magnet yang kuat di dalam kumparan dikarenakan hukum induksi Faraday. Induktor adalah salah satu komponen elektronik dasar yang digunakan dalam rangkaian yang arus dan tegangannya berubah-ubah dikarenakan kemampuan induktor untuk memproses arus bolak-balik. Induktansi $(L)$ (diukur dalam Henry) 
adalah efek dari medan magnet yang terbentuk disekitar konduktor pembawa arus yang bersifat menahan perubahan arus.

Purwanto (2014: 44) mengungkapkan bahwa hasil "belajar seringkali digunakan sebagai ukuran untuk mengetahui seberapa jauh seseorang menguasai bahan yang sudah diajarkan".Untuk mengaktualisasikan hasil belajar tersebut diperlukan serangkaian pengukuran menggunakan alat evaluasi yang baik dan memenuhi syarat. Hasil belajar dapat dijelaskan dengan memahami dua kata yang membentuknya, yaitu "hasil" dan "belajar". Pengertian hasil (product) menunjukan pada suatu perolehan akibat dilakukannya suatu aktivitas atau proses yang mengakibatkan perubahannya input secara fungsional.

Muslich (2011: 38) mengatakan bahwa hasil belajar merupakan "kemampuan-kemampuan yang dimiliki peserta didik setelah ia menerima pengalaman belajar". Menurut Sudijono (2009: 31) evaluasi hasil belajar dapat dikatakan terlaksana dengan baik apabila dalam pelaksanaannya senantiasa berpegang pada tiga prinsip dasar yaitu "(1) prinsip keseluruhan, (2) prinsip kesinambungan, dan (3) prinsip obyektivitas".

\section{Metode}

Metode penelitian yang digunakan dalam penelitian ini adalah metode scientific dilakukan pada siswa kelas X di SMK 1 GamalielMadiun yang diambil satu kelas. Metode pembelajaran adalah metode scientificberbasis e-bookpenelitian ini menggunakan One Group PretestPosttest Design, karena hanya melakukan penelitian dengan satu kelas saja. Sebuah kelompok diukur atau diamati tidak hanya setelah perlakuan.

Penelitian disusun sesuai dengan variabel-variabel yang terlibat. Variabel-variabel yang terlibat dalam penelitian ini merupakan cerminan dari data-data yang akan diperoleh setelah perlakuan. Menururt Sugiyono, (2008: 2) variabel penelitian pada dasarnya adalah "segala sesuatu yang berbentuk apa saja yang ditetapkan oleh penelitian untuk dipelajari sehingga diperoleh informasi tentang hal tersebut, kemudian ditarik kesimpulannya". Maka dapat dirumuskan bahwa variabel penelitian adalah suatu atribut atau sifat atau nilai orang, obyek atau kegiatan yang mempunyai variasi tertentu yang ditetapkan oleh peneliti untuk dipelajari dan ditarik kesimpulannya

\section{Hasil dan Pembahasan}

Uji hipotesis ini dilakukan dengan menggunakan uji statistik korelasi product moment.terhadap nilai hasil belajar pada sebelumperlakuan(pretest)dan sesudahperlakuan(posttest)dengan menggunakan statistik korelasi product moment dengan taraf signifikan 5\%. Kriteria ujinya adalah sebagai berikut ini $\mathrm{H}_{0}$ diterima / $\mathrm{H}_{\mathrm{a}}$ ditolak jika $\mu_{1}$ $\neq \mu_{2}$ dan $\mathrm{H}_{0}$ ditolak / $\mathrm{H}_{1}$ diterima jika $\mu_{1}=\mu_{2 . .}$ Dari hasil analisis uji hipotesis diperoleh statistik korelasi product moment $=0,951$ dan statistik korelasi product moment $\mathrm{r}_{\text {tabel }}=0,444$ Karena $\mu_{1}=\mu_{2}$. Berdasarkan uji hipotesis yang diperoleh $\mu_{1}(0,91) \neq \mu_{2}(0,444)$ maka $\mathrm{H}_{0}$ ditolak. Jadi, dapat disimpulkan bahwa ada pengaruh penerapanmedia pembelajaran E-book dengan pendekatan scientific untukmeningkatkanhasilbelajar siswa pada mata pelajaran Rangkaian Induktor. 
Tabel 1. Rangkuman Uji Homogenitas

\begin{tabular}{|c|c|c|c|c|c|}
\hline NO & PRETEST $(\mathrm{x})$ & POSTEST (y) & $x^{2}$ & $y^{2}$ & $x y$ \\
\hline$\Sigma$ & 570 & 1720 & 19400 & 149700 & 51275 \\
\hline$X$ & 28,50 & 86,00 & & & \\
\hline rxy & 0,951 & & & & \\
\hline tabel & 0,444 & & & & \\
\hline
\end{tabular}

Berdasarkan tabel 1 dapat disimpulkan bahwa:

1) Terdapat perbedaan pengaruh dengan menggunakan model discovery learning dengan pendekatan scientific berbasis e-book pada materi rangkaian induktor.

2) Terdapat peningkatan hasil belajar siswa.

Berdasarkan perhitungan uji analisis dengan jumlah siswa keseluruhan 20 orang siswa. Hasil penelitin nilai sebelum perlakuan (pretest)rata-rata 28,5 dan nilai setelah perlakuan (posttest) rata-rata 86, dalam hal ini menunjukkan ketercapaian keberhasilan dalam penelitian ini dari segi kognitif dapat dilihat ada peningkatan nilai hasil belajar antara sebelum perlakuan (pretest)dan sesudah perlakuan (posttest),

Berdasarkan data yang diperoleh diketahui bahwa nilai minimum adalah 10 dan nilai maksimum $=55$. Selain itu, diperoleh nilai mean $=28.5$, median $=30$, modus $=35$ data selengkapnyadapatdilihatpada lampiran 10. Selanjutnya, dariskorteshasilbelajar yang dicapaisiswa (nilaipretest) dapatdisusun distribusi frekuensi bergolong seperti yang ditunjukkan pada tabel

Tabel 2. Tabulasi Data Skor Tes Hasil Belajar sebelum perlakuan (Pretest)

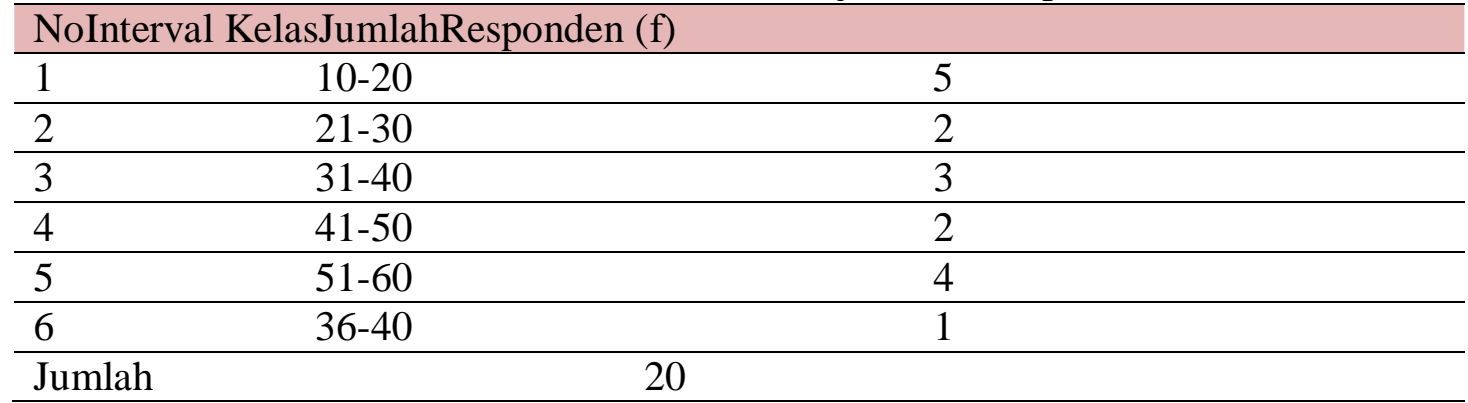

Berdasarkan data pada tabel 4.1. di atas, bentuk grafik skor pretest, yaitu hasil belajar sebelum dilakukan perlakuanberupa pembelajaran menggunakan media pembelajarane-book, dapat digambarkan sebagai berikut:

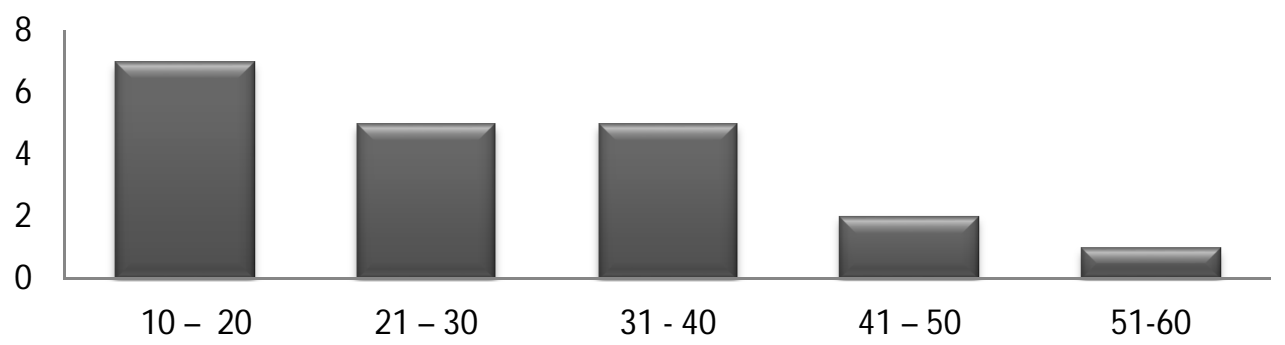

Grafik 3.Histogram SkorTesHasilBelajar Dasar dan Pengukuran Listrik Sebelum Perlakuan (Pretest) 
Setelahpelaksanaanpembelajaran Rangkaian Induktor menggunakan media pembelajaranEbook dengan pendekatan scientific, dilaksanakantes (posttest) untukmemperoleh data hasilbelajarsiswa.Data skortes (posttest) diperoleh dari sampel sebanyak 20 siswa. Berdasarkan data yang diperoleh diketahui bahwa nilai minimum adalah 75 dan nilai maksimum $=100$. Sedangkan nilai mean $=86$, median $=85$, dan modus $=75$ data selengkapnyadapatdilihatpadalampiran lampiran 11. Selanjutnya, dariskorteshasilbelajar yang dicapaisiswa (nilaiposttest) dapatdisusun distribusi frekuensi bergolong seperti yang ditunjukkan pada tabel 4.2.

Tabel 4.Tabulasi Data Skor Tes Hasil Belajar sesudah perlakuan (Posttest)

\begin{tabular}{lcc}
\hline \multicolumn{2}{l}{ NoInterval KelasJumlahResponden (f) } \\
\hline 1 & $70-80$ & 8 \\
\hline 2 & $81-90$ & 6 \\
\hline 3 & $91-100$ & 6 \\
\hline & Jumlah & 20 \\
\hline
\end{tabular}

Berdasarkan data pada tabel 4.2. di atas, bentuk grafik skor posttest, yaitu hasil belajar setelah dilakukan perlakuanberupa pembelajaran menggunakan media pembelajaranEbook dengan pendekatan scientific, dapat digambarkan sebagai berikut:

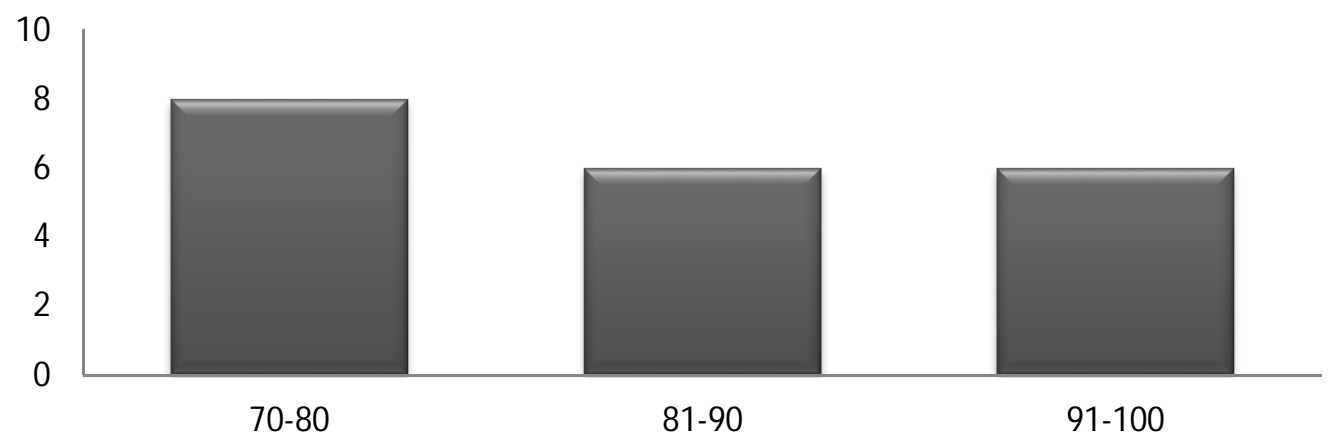

Grafik 5. Histogram SkorTesHasilBelajar Dasar dan Pengukuran ListrikSesudah Perlakuan (Posttest)

Hasil nilai pretest dan posttest dapat digambarkan sebagai berikut: Nilai rata-rata

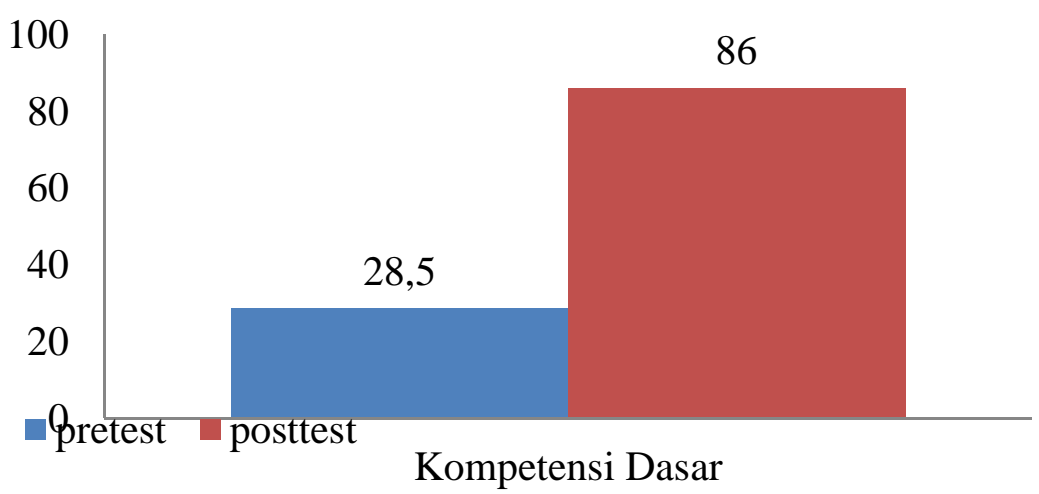

Grafik 6. Histogram Tes Hasil Belajar Dasar dan Pengukuran Listrik Sesudah Perlakuan 
Uji normalitas digunakan untuk mengetahui data yang diperoleh dari sampel yang diambil dari suatu populasi berdistribusi normal atau tidak. Pada penelitian ini peneliti menggunakan Liliefors untuk uji normalitasnya, dengan taraf signifikan $\propto=0,05$. Daerah kritik pada uji ini adalah $\mathrm{DK}=\left\{\mathrm{LlL}>\mathrm{L}_{0.05 ; 20}\right\}$. Dari hasil analisis uji normalitas dengan kriteria ujinya adalah Ho diterima $/ \mathrm{H}_{1}$ ditolak jika $\mathrm{L}_{\mathrm{obs}}<\mathrm{L}_{\text {tabel }}$ dan $\mathrm{Ho}$ ditolak $/ \mathrm{H}_{1}$ diterima jika $\mathrm{L}_{\mathrm{obs}}>\mathrm{L}_{\text {tabel. }}$. Dari analisis uji normalitas pada sebelumperlakuan (pretest) dapat diketahui nilai $\mathrm{L}_{\mathrm{obs}} 0,095<$ $\mathrm{L}_{\text {tabel }}$ 0,19 maka Ho diterima. Sedangkan setelahperlakuan (posttest) diketahui nilai $\mathrm{L}_{\mathrm{obs}}$ 0,082 $<\mathrm{L}_{\text {tabel }}$ 0,19 maka Ho diterima, sehingga data yang diperoleh tespretest dan tesposttest berasal dari populasi yang berdistribusi normal. Dataselengkapnya dapat dilihat dilampiran 16 dan 17.

Tabel 7. Hasil Analisis Uji Normalitas

\begin{tabular}{cclll}
\hline Tes & \multicolumn{1}{c}{ Lhitung } & \multicolumn{1}{c}{$\mathbf{L}_{\text {tabel }}$} & $\begin{array}{c}\text { Keputusan } \\
\text { uji }\end{array}$ & Kesimpulan \\
\hline Pretest & 0,095 & $\begin{array}{l}\mathrm{L}_{(0,19 ; 20)}= \\
0,190\end{array}$ & $\mathrm{H}_{0}$ diterima & $\begin{array}{l}\text { Berdistribusi } \\
\text { Normal }\end{array}$ \\
\hline Posttest & 0,082 & $\mathrm{~L}_{(0,19 ; 20)}=$ & $\mathrm{H}_{0}$ diterima & $\begin{array}{l}\text { Berdistribusi } \\
\text { Normal }\end{array}$ \\
\hline
\end{tabular}

\section{b. Uji Homogenitas}

Uji homogenitas dipakai dengan tujuan untuk mengetahui sama atau tidaknya variansivariansi dari sejumlah populasi. Peneliti menguji homogenitas sebelumperlakuan (Pretest)dansesudahperlakuan(Posttest) dengan menggunakan rumus uji $\mathrm{F}$ dengan taraf signifikansi 5\%. Hasil analisis data uji homogenitas dari data nilai hasil belajar mahasiswa disajikan dalam tabel berikut:

Tabel 8. Hasil Analisis Uji Homogenitas

\begin{tabular}{cccc}
\hline $\mathrm{F}_{\text {hitung }}$ & $\mathrm{F}_{\text {tabel }}$ & Kriteria & Keputusan Uji \\
\hline 1,77 & $F_{0,05(20,20)}=2,15$ & $F_{\text {hitung }} \leq F_{\text {tabel }}$ & $H_{o}$ diterima \\
\hline
\end{tabular}

Dari tabel di atas dapat disimpulkan bahwa sampel dari tessebelumperlakuan (pretest)dantessesudahperlakuan (posttest)berasal dari populasi yang memiliki varians homogen.

\section{Simpulan}

Berdasarkan hasil analisis yang telah dibahas, diperoleh kesimpulan bahwa dari hasil analisis uji hipotesis diperoleh statistik korelasi product moment $=0,951$ dan statistik korelasi product moment $\mathrm{r}_{\text {tabel }}=0,444$ karena $\mu_{1}=\mu_{2}$. Berdasarkan uji hipotesis yang diperoleh $\mu_{1}(0,951) \neq \mu_{2}(0,444)$ maka $\mathrm{H}_{0}$ ditolak dan $\mathrm{H}_{\mathrm{a}}$ diterima. Jadi, dapat disimpulkan bahwa ada pengaruh penerapanmedia pembelajaranE-book dengan pendekatan scientific untukmeningkatkanhasilbelajar siswa pada mata pelajaran Rangkaian Induktor. 


\section{Daftar Pustaka}

[1] Arikunto, S. (2013).Dasar-dasar Evaluasi Pendidikan. Jakarta: Bumi Aksara.

[2] Arsyad, A. (2014). Media Pembelajaran. Jakarta: Rajawali Pers.

[3] Baharuddin \& Wahyuni, E, N. (2007).Teori Belajar dan Pembelajaran. Jogjakarta: Arruzz Media.

[4] Hanafiah, N \& Suhana, C. (2012).Konsep Strategi Pembelajaran. Bandung: PT. Refika Aditama.

[5] Ine, M, E. (2015). Penerapan Pendekatan Scientific Untuk Meningkatkan Prestasi Belajar Siswa Pada Mata Pelajaran Ekonomi Pokok Bahasan Pasar. Universitas Negeri Surabaya, diunduh pada2 Maret 2017.

[6] Koriaty, S \& Manggala, E. (2016).Penerapan Media E-book Terhadap MinatBelajar $\begin{array}{llllll}\text { Siswa } & \text { Di } & \text { Kelas } & X & \text { Jurusan } & \text { TKJ }\end{array}$ SMK Negeri 4 Pontianak, diunduh pada 25 Maret 2017

[7] Majid, \& Rochman, C. (2014). Pendekatan Ilmiah Dalam Implementasi Kurikulum 2013. Bandung: PT. Remaja Rosdakarya.

[8] Muslich, M. (2011).Penilaian Berbasis Kelas dan Komputer. Bandung: PT. Refika Aditama.

[9] Mundir. (2013). Statistik Pendidikan. Jogjakarta: Pustaka Pelajar.

[10] Purwanto. (2014). Evaluasi Hasil Belajar. Yogyakarta: Pustaka Pelajar.

[11] Poerwati, L, E \& Amri, S. (2013).Kurikulum 2013. Jakarta: PT. Prestasi Pustakarya.

[12] Sadiman dkk.(2011).Media Pendidikan. Jakarta: Rajawali Pers.

[13] Slameto.(2010).Belajar dan Faktor-faktor yang Mempengaruhinya. Jakarta: PT. Rineka Cipta.

[14] Siregar, E \& Nara, H. (2011).Teori Belajar dan Pembelajaran. Bogor: Ghalia Indonesia.

[15] Siregar, S. (2014).StatistikParametrikuntukPenelitianKuantitatif. Jakarta: BumiAksara.

[16] Sudijono, A. (2009).Evaluasi Pendidikan. Jakarta: Rajawali Pers.

[17] Sugiyono.(2008).Statistika Untuk Penelitian. Bandung: CV. Alfabeta.

[18] Sundayana, R. (2014). Statistika penelitian pendidikan. Bandung: CV. Alfabeta.

[19] Suryani, N \& Agung, L. (2012).Strategi Belajar Mengajar. Yogyakarta: Ombak.

[20] Tumurun, S, W. dkk.(2016).Pengaruh Model Pembelajaran Discovery Learning Terhadap Keterampilan Berfikir Kreatif Siswa Pada Materi Sifat-sifat Cahaya. Program Studi PGSD Kelas UPI Kampus Sumedang

[21] Wahjudi, E. (2015). Penerapan Discovery Learning Dalam Pembelajaran IPA Sebagai Upaya Untuk Meningkatkan Hasil Belajar Siswa Kelas IX-I di SMP Negeri 1 Kalianget

[22] Widodo, S. 2013.Dasar dan Pengukuran Listrik.Kementrian Pendidikan Dan Budaya.

[23] Yudistiya, S. (2014). Pengembangan Media E-book Pada Mata Pelajaran Bahasa Inggris Kelas X di SMA Negeri 2 padang panjang 